\title{
molecules
}

ISSN 1420-3049

(C) 2007 by MDPI

www.mdpi.org/molecules

Full Paper

\section{4'-Acetamidochalcone Derivatives as Potential Antinociceptive Agents}

Fátima de Campos-Buzzi ${ }^{1,2}$, Pâmela Padaratz ${ }^{1}$, Aleandra Vergilina Meira ${ }^{1}$, Rogério Corrêa ${ }^{1}$, Ricardo José Nunes ${ }^{2}$ and Valdir Cechinel-Filho ${ }^{1, *}$

${ }^{1}$ Núcleo de Investigações Químico-Farmacêuticas (NIQFAR)/CCS, Universidade do Vale do Itajaí (UNIVALI), Itajaí-SC, Brazil

2 Departamento de Química, Universidade Federal de Santa Catarina (UFSC), Florianópolis-SC, Brazil

* Author to whom correspondence should be addressed; e-mail: cechinel@univali.br; Phone: (+55) 473341 7525; Fax: (+55) 4733417601

Received: 22 March 2007; in revised form: 22 April 2007 / Accepted: 24 April 2007 / Published: 30 April 2007

\begin{abstract}
Nine acetamidochalcones were synthesized and evaluated as antinociceptive agents using the mice writhing test. Given intraperitoneally all the compounds were more effective than the two reference analgesic drugs (acetylsalicylic acid and acetaminophen) used for comparison. $N$-\{4-[(2E)-3-(4-nitrophenyl)prop-2-enoyl]phenyl $\}$ acetamide (6) was the most effective compound and was therefore selected for more detailed studies. It caused dose-related inhibition in the writhing test, being about 32 to 34-fold more potent than the standard drugs. It was also effective in the second phase of the formalin test and the capsaicin test. These acetamidochalcones, especially compound 6, might be further used as models to obtain new and more potent analgesic drugs.
\end{abstract}

Keywords: Acetamidochalcones, antinociception, mice

\section{Introduction}

Naturally-occurring and synthetic chalcone compounds have shown promising biological activity and safety profiles and have shown potential for use as lead compounds for the discovery of 
antioxidant, anti-inflammatory, anticancer or anti-infective agents [1]. A number of chalcones and their derivatives have also been found to inhibit the synthesis of nitric oxide (NO) and prostaglandins (PG), which are products of the nitric oxide synthase (NOS) and cyclooxygenase (COX) pathways, respectively [2,3]. Recently, Nowakovska published a review of the anti-infective and antiinflammatory activity of chalcones, which constitute a unique template that is associated with diverse biological activities [4].

Previous studies carried out by our research group have revealed that some simple synthetic chalcones, or those derived from the abundant natural product 2-hydroxy-4,6-dimethoxyacetophenone, exhibit pronounced antinociceptive effects in the mice writhing test $[5,6]$. The present study reports on the antinociceptive effects of some synthetic acetamidochalcones in this test. The most active compound was evaluated in more detail in other pain models. The results of two well-known analgesic agents, acetylsalicylic acid and acetaminophen, were included as positive controls for comparison purposes.

\section{Results and Discussion}

A series of chalcones which possess an acetamido substituent at the 4'-position of ring $\mathrm{A}$ and different substituent groups in the 3 or 4-positions of ring B (compounds 1-7) or different aromatic heterocycles in the ring B position (compounds 8 and 9) were synthesized (Scheme 1). All the compounds were obtained in good yields (72-95 \%), and were characterized by conventional spectral data. Inspection of the ${ }^{1} \mathrm{H}-\mathrm{NMR}$ spectra suggested that the chalcones were geometrically pure and presented trans configurations $(J=15-16 \mathrm{~Hz})$ [7].

Scheme 1. Synthesis of 4'-acetamidochalcones.

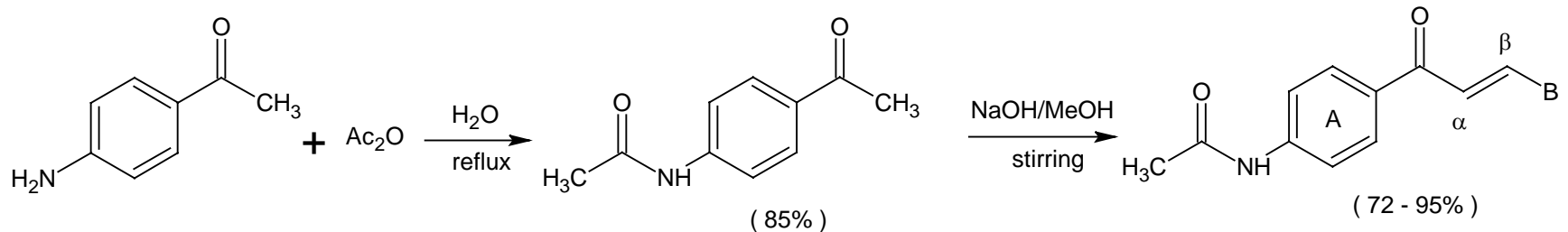

$\mathrm{B}=-\mathrm{C}_{6} \mathrm{H}_{5}$ (1); 4- $-\mathrm{OCH}_{3} \mathrm{C}_{6} \mathrm{H}_{4}$ (2); 4- $\mathrm{CH}_{3} \mathrm{C}_{6} \mathrm{H}_{4}$ (3); 4- $\mathrm{ClC}_{6} \mathrm{H}_{4}$ (4); 3,4- $\mathrm{Cl}_{2} \mathrm{C}_{6} \mathrm{H}_{3}$ (5); 4- $\mathrm{NO}_{2} \mathrm{C}_{6} \mathrm{H}_{4}$ (6); - $\mathrm{N}\left(\mathrm{CH}_{3}\right)_{2} \mathrm{C}_{6} \mathrm{H}_{4}$ (7); - $\mathrm{C}_{5} \mathrm{H}_{3} \mathrm{~S}(\mathbf{8}) ;-\mathrm{C}_{5} \mathrm{H}_{3} \mathrm{O}(\mathbf{9})$.

In this study, the antinociceptive activity for all the compounds indicated in Table 1 was initially evaluated using the acetic acid-induced writhing test in mice after intraperitoneal administration of a $10 \mathrm{mg} / \mathrm{kg}$ dose. Among the synthesized compounds, the most effective were chalcones 2, 3, 6, 7 and 9, which caused inhibitions of 91.6, 85.4, 94.1, 84.1 and $90.9 \%$, respectively, although all the chalcones significantly inhibited the induced abdominal constrictions and were more effective than the two analgesic drugs, (acetylsalicylic acid and acetaminophen), which caused inhibitions of 35\% and 38\%, respectively, in the same model and at the same dose. Analyzing the more outstanding results, 
especially compounds 2, $\mathbf{6}$ and 9, it can be observed that the electronic parameters (by induction, or resonance, or both) in the ring B do not appear to influence the analgesic activity.

Table 1. Antinociceptive activity of 4'-acetamidochalcones, acetylsalicylic acid (ASA) and acetaminophen (ACE) against acetic acid-induced abdominal constrictions in mice.

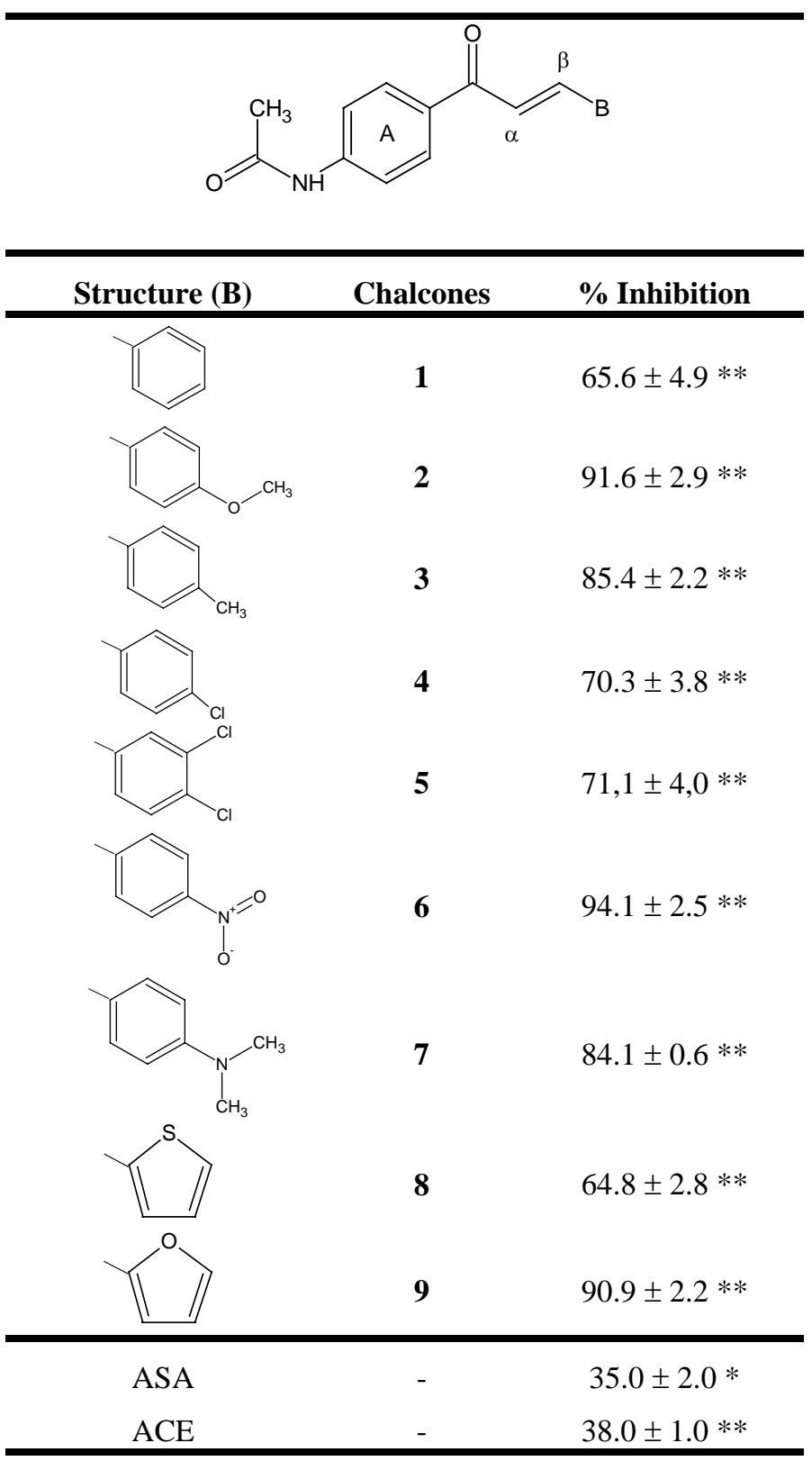

Each group represents the mean \pm s.e.m. of 6-8 experiments. Compounds, acetylsalicylic acid and acetaminophen were administered intraperitoneally at $10 \mathrm{mg} / \mathrm{kg} ;{ }^{* *} p<0.01$ and ${ }^{*} \mathrm{p}<$ 0.05 compared with the corresponding control value. 
A preliminary attempt to correlate the activity with some structural parameters, such as the hydrophobic, steric or electronic effects of the substituent groups in ring B using the HyperChem software program proved unsuccessful. Nevertheless, further studies are in progress to determine the possible involvement of other structural parameters (molecular, topological, geometrical, etc.), and these results will be published elsewhere in due course.

Compound 6, which possesses a nitro group in the 4-position of ring $B$, showed the most significant inhibitory activity, causing a $94.1 \%$ inhibition in the writhing test. This compound was therefore selected for more detailed studies in this and other tests. The $\mathrm{ID}_{50}$ of this chalcone was determined and the result is shown in Figure 1. It was observed that this compound, administered intraperitoneally, caused a potent and dose-dependent antinociceptive effect, with a ID $_{50}$ value of 1.22 $\mathrm{mg} / \mathrm{kg}$ (3.93 $\mu \mathrm{mol} / \mathrm{kg}$, i.p.), being about 32 to 34-fold more potent than the standard drugs (acetaminophen and acetylsalicylic acid) used as references, which presented $\mathrm{ID}_{50}$ values of 125 and $133 \mu \mathrm{mol} / \mathrm{kg}$, i.p., respectively, in the same experimental model.

Figure 1. Effect of compound 6 (0.1, 0.5, 1,3 and $10 \mathrm{mg} / \mathrm{kg})$, given intraperitoneally, against acetic acid $0.6 \%$ induced abdominal constrictions in mice. Each column represents the mean s.e.m. of six to eight experimental values. ${ }^{*} \mathrm{p}<0.05$; ${ }^{* *} \mathrm{p}<0.01$.

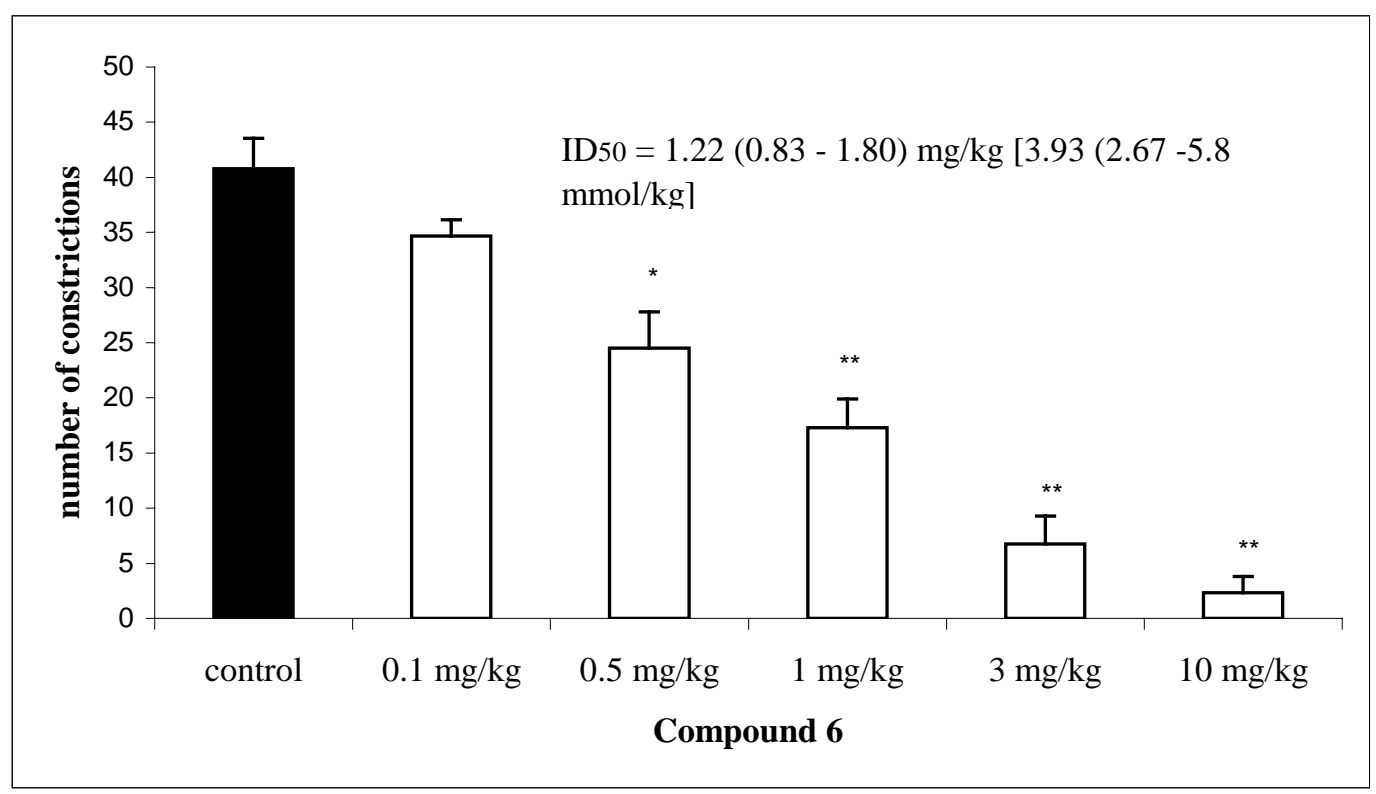

Compound 6 was also examined in the formalin-induced pain test, a reported behavior model characterized by neurogenic (first) and inflammatory (second) phases [8,9]. The results (Figure 2) revealed that both the chalcone and acetylsalicylic acid (control drug), were inactive in preventing the first phase of formalin-induced (neurogenic) pain at $10 \mathrm{mg} / \mathrm{kg}$, i.p. However, compound 6 significantly inhibited the second phase (inflammatory) pain, with a $60.8 \%$ inhibition, whereas acetylsalicylic acid only displayed a $39.0 \%$ inhibition. 
Figure 2. Effect of compound 6 (10 mg/kg), given intraperitoneally, against the first (0 to $5 \mathrm{~min}$ ) and second (15 to $30 \mathrm{~min}$ ) phases in a formalin test in mice. Each column represents the mean s.e.m. of six to eight experimental values. ${ }^{*} \mathrm{p}<0.05$; ${ }^{* *} \mathrm{p}<0.01$.

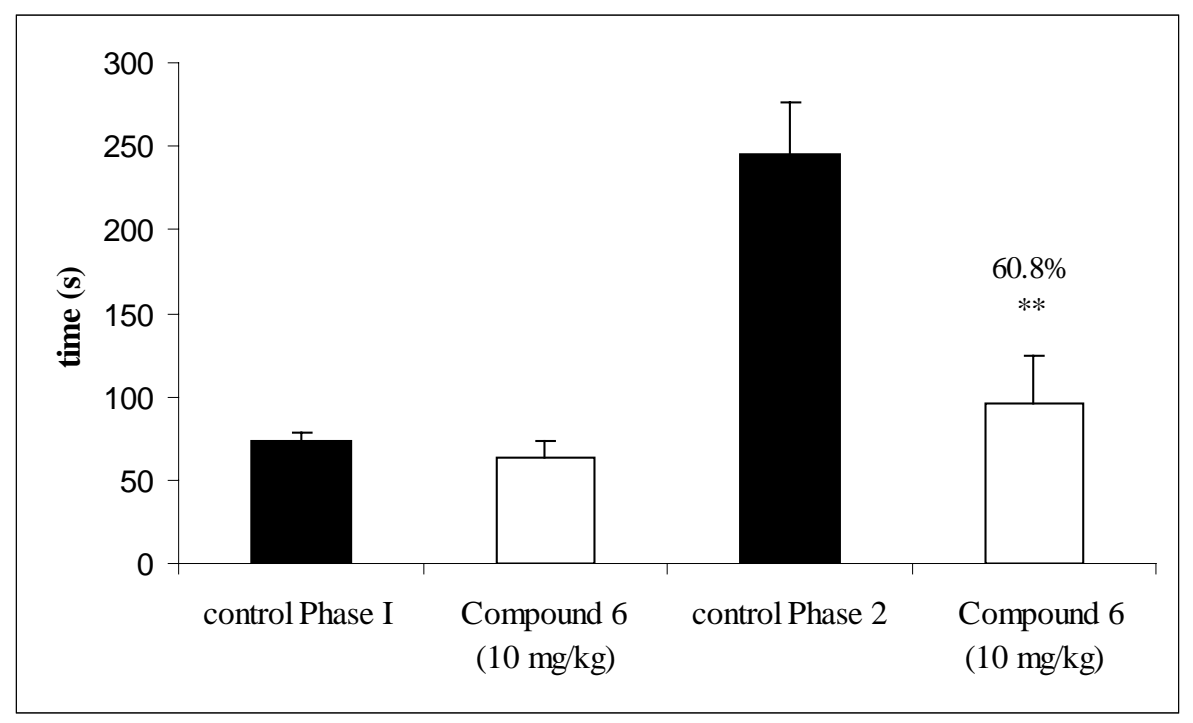

On the other hand, chalcone 6 (10 mg/kg, i.p.) exhibited considerable antinociceptive activity in the capsaicin test, causing a $70.0 \%$ inhibition of capsaicin induced licking and thus providing more direct evidence of the effects of this compound on neurogenic pain. This suggests its involvement with the antagonism of the vanilloid receptor (Figure 3).

Figure 3. Effect of compound 6 (10 mg/kg), on licking/biting response induced by intraplantary injection of capsaicin in mice. Each group represents the mean of six to eight experiments. ${ }^{* *} \mathrm{p}<0.01$, compared with the corresponding control value.

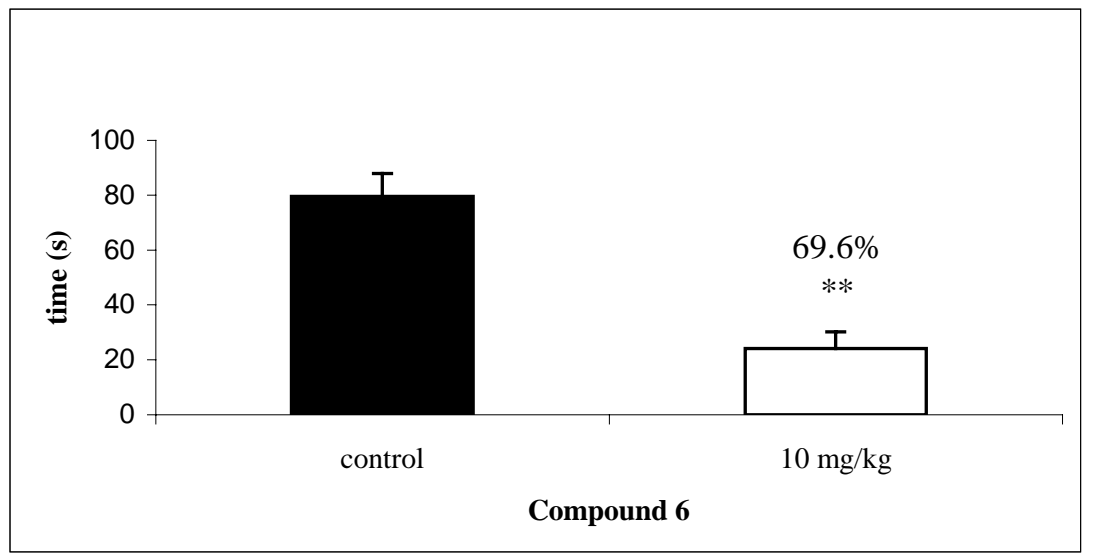

While compound 6, like acetylsalicylic acid and acetaminophen (and several non-steroidal antiinflammatory and analgesic drugs), was effective in suppressing acetic acid-induced pain in a nonopioid pathway, a lack of antinociceptive effects (results not shown) was observed in the hot-plate test, a technique that is selective for opioid-derived analgesics [10]. Although the presence of the nitro group in ring B (compound 6) may suggest a possible toxic action, in accordance with the literature 
[11,12], our experiments did not indicate any signs of toxicity in the animals. Preliminary tests using Artemia saline (Brine Shrimp) larvae demonstrated low toxicity for these molecules. In this context, some clinically used drugs possess nitro group(s) in their structure, such as the well-documented nimesulide, a non-steroidal anti-inflammatory drug used to treat inflammation and pain [13], which encourages us to continue these investigations.

\section{Conclusions}

In summary, the acetamidochalcones evaluated in this work demonstrated significant antinociceptive activity against acetic acid-induced abdominal constrictions. When given intraperitoneally, all the chalcones synthesized were more active than the reference drugs, acetylsalicylic acid and acetaminophen, in particular compound 6, which indicated an interesting antinociceptive profile. Pharmacological studies are in progress to confirm the antinociceptive potential of the most active compounds in other models and routes of administration and to characterize the precise mechanism(s) of action of these acetamidochalcones. Finally, the findings of this study suggest that acetamidochalcones may represent an important class of novel and potent analgesic agents. The precise mechanism of action remains to be determined, but it does not involve the opioid system, and probably involves interaction with the vanilloid system and/or the mediators of the inflammatory process induced by formalin.

\section{Experimental}

\section{General}

The melting points were determined using a Microquimica WG APF-301 apparatus, and are uncorrected. The infrared (IR) spectra were recorded in $\mathrm{KBr}$ disks on a Perkin-Elmer $16 \mathrm{PC}$ spectrometer. The ${ }^{1} \mathrm{H}$ - and ${ }^{13} \mathrm{C}-\mathrm{NMR}$ spectra were recorded in DMSO- $d_{6}$ using a Bruker WM $300 \mathrm{MHz}$ spectrometer. Results are expressed in ppm downfield from the signal of TMS used as internal standard. Elemental analysis $\mathrm{C}$ and $\mathrm{H}$ percentages of were in agreement with the product formulae (within $\pm 0.4 \%$ of theoretical values). The purity of the synthesized substances was monitored by thinlayer chromatography (TLC) using silica gel $60 \mathrm{~F}_{254}$ pre-coated aluminum sheets (Merck ${ }^{\circledR}$ ) with several solvent systems of different polarities. The compounds were visualized with ultraviolet light (254 nm) and purified by recrystallization from ethyl alcohol and water or by column chromatography on silica gel (Merck, 60-120 mesh) eluting with hexane/ethyl acetate solvent systems of different polarities.

\section{Chemistry: Synthesis of $N$-(p-acetylphenyl)acetamide}

A solution of p-aminoacetophenone $(2.2 \mathrm{~g}, 16.27 \mathrm{mmol})$ in water was stirred at room temperature, followed by the addition of acetic anhydride $(4.1 \mathrm{~mL}, 43.43 \mathrm{mmol})$. The reaction mixture was then heated at reflux for $2 \mathrm{~h}$. The solution was cooled in an ice bath and the resulting crystals were washed with cool water and filtered under vacuum, giving an $85.0 \%$ yield of the title compound. 
Synthesis of acetamidochalcones 1-9

A $50 \% \mathrm{w} / \mathrm{v}$ aq. $\mathrm{NaOH}$ solution $(1.5 \mathrm{~mL})$ was added to a well stirred solution of $\mathrm{N}$ - $(p$-acetylphenyl)acetamide $(1.7 \mathrm{mmol})$ and the appropriate substituted benzaldehyde $(1.7 \mathrm{mmol})$ in methanol (50 mL). The reaction mixture was stirred overnight at room temperature, according to the previously described methodology [14]. It was then neutralized with $1 \mathrm{~N} \mathrm{HCl}$ and the product filtered and extracted with chloroform. The combined organic layers were dried $\left(\mathrm{Na}_{2} \mathrm{SO}_{4}\right)$, filtered and evaporated. The products were purified by column chromatography or recrystallization from ethyl alcohol or ethyl alcohol and water.

$N$-\{4-[(2E)-3-phenylprop-2-enoyl]phenyl \}acetamide (1): Yield: 80 \%; m.p.: 161.7-162.2 ${ }^{\circ} \mathrm{C}$; FT-IR (v,

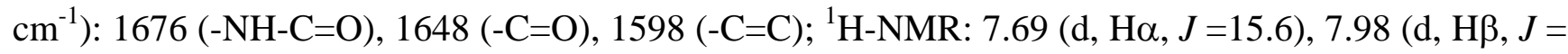
15.6), 7.81-7.39 (m, Ar); 2.20 (s, $\left.\mathrm{OCCH}_{3}\right)$; ${ }^{13} \mathrm{C}-\mathrm{NMR}: 189.3$ (C=O), 121.7 (C $\alpha$ ), 144.7 (C $\left.\beta\right), 142.5$ (C$\mathrm{N}), 169.1(\mathrm{~N}-\mathrm{C}=\mathrm{O}), 24.6\left(-\mathrm{CH}_{3}\right)$; Anal. Calc. for $\mathrm{C}_{17} \mathrm{H}_{15} \mathrm{NO}_{2}(\mathrm{MW}=265.3) \mathrm{C}: 76.96, \mathrm{H}:$ 5.70, N: 5.28, found C: 76.91, H: 5.64, N: 5.20 .

$N$-\{4-[(2E)-3-(4-metoxyphenyl)prop-2-enoyl]phenyl\}acetamide (2): Yield: 84 \%; m.p.: 206.5-207.0

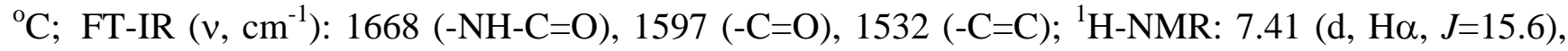
7.73 (d, H $\beta, J=15.6), 6.92-8.02$ (m, Ar), 3.85 (s, - $\left.-\mathrm{OCH}_{3}\right), 2.23$ (s, $\left.\mathrm{OCCH}_{3}\right), 1.6(\mathrm{NH}) ;{ }^{13} \mathrm{C}-\mathrm{NMR}: 189.3$ $(\mathrm{C}=\mathrm{O}), 119.1(\mathrm{C} \alpha), 144.7(\mathrm{C} \beta), 142.1(\mathrm{C}-\mathrm{N}), 168.7(\mathrm{~N}-\mathrm{C}=\mathrm{O}), 55.7\left(\mathrm{OCH}_{3}\right), 25.1\left(-\mathrm{CH}_{3}\right)$; Anal. Calc. for $\mathrm{C}_{18} \mathrm{H}_{17} \mathrm{NO}_{3}(\mathrm{MW}=295.3) \mathrm{C}: 73.20, \mathrm{H}: 5.80, \mathrm{~N}$; 4.74, found $\mathrm{C}: 73.11, \mathrm{H}: 5.76, \mathrm{~N}: 4.69$.

$N$-\{4-[(2E)-3-(4-methylphenyl)prop-2-enoyl]phenyl\}acetamide (3): Yield = 79 \%; m.p.: 197.5-199.0

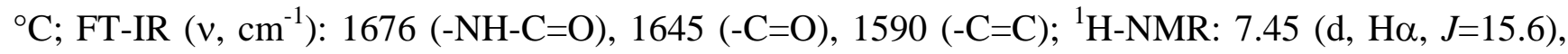
7.79 (d, H $\beta, J=15.6), 7.21-8.03$ (m, Ar), 2.39 (s, $\mathrm{CH}_{3}$ ), 2.23 (s, $\left.\mathrm{OCCH}_{3}\right) ;{ }^{13} \mathrm{C}-\mathrm{NMR}: 189.3(\mathrm{C}=\mathrm{O})$, $120.9(\mathrm{C} \alpha), 144.9(\mathrm{C} \beta), 141.3(\mathrm{C}-\mathrm{N}), 25.1\left(\mathrm{OCCH}_{3}\right), 21.8\left(-\mathrm{CH}_{3}\right)$; Anal. Calc. for $\mathrm{C}_{18} \mathrm{H}_{17} \mathrm{NO}_{2}(\mathrm{MW}=$ 279.33) C: 77.40, H: 6.13, N: 5.01, found C: 77. 33, H: 6.09, N: 4.92.

$N$-\{4-[(2E)-3-(4-chlorophenyl)prop-2-enoyl]phenyl\}acetamide (4): Yield = 83 \%; m.p.: 215.0-215.7

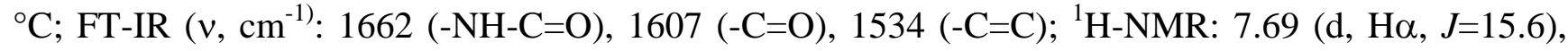
7.94 (d, H $\beta, J=15.6$ ), 7.50 - 8.15 (m, Ar), 2.1 (s, $\left.\mathrm{OCCH}_{3}\right)$; ${ }^{13} \mathrm{C}-\mathrm{NMR}: 188.1(\mathrm{C}=\mathrm{O}), 123.4(\mathrm{C} \alpha), 142.5$ $(\mathrm{C} \beta), 144.5(\mathrm{C}-\mathrm{N}), 169.7(\mathrm{~N}-\mathrm{C}=\mathrm{O}), 135.6(\mathrm{C}-\mathrm{Cl}), 24.9\left(-\mathrm{CH}_{3}\right)$. Anal. Calc. for $\mathrm{C}_{17} \mathrm{H}_{14} \mathrm{ClNO}_{2}(\mathrm{MW}=$ 299.75) C: 68.12, H: 4.71, N: 4.67, found C: 68.08, H: 4.69, N: 4.61.

$N$-\{4-[(2E)-3-(3,4-dichlorophenyl)prop-2-enoyl]phenyl\}acetamide (5): Yield = 95 \%; m.p.: 210.4-

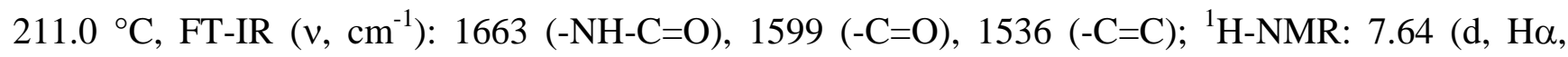
$J=15.6$ ), 8.0 (d, H $\beta, J=15.6$ ), 7.65 - 8.23 (m, Ar), 2.07 (s, $\left.\mathrm{OCCH}_{3}\right) ;{ }^{13} \mathrm{C}-\mathrm{NMR}: 187.9(\mathrm{C}=\mathrm{O}), 169.7$ (N$\mathrm{C}=\mathrm{O}), 124.7(\mathrm{C} \alpha), 141.1(\mathrm{C} \beta), 144.6(\mathrm{C}-\mathrm{N}), 131.6-130.7(\mathrm{C}-\mathrm{Cl}), 24.9\left(-\mathrm{CH}_{3}\right)$; Anal. Calc. for $\mathrm{C}_{17} \mathrm{H}_{13} \mathrm{Cl}_{2} \mathrm{NO}_{2}(\mathrm{MW}=334.20) \mathrm{C}: 61.10, \mathrm{H}: 3.92, \mathrm{~N}: 4.19$, found $\mathrm{C}: 61.0, \mathrm{H}: 3.87, \mathrm{~N}: 4.14$.

$N$-\{4-[(2E)-3-(4-nitrophenyl)prop-2-enoyl]phenyl\}acetamide (6): Yield = 89 \%; m.p.: 239.7-241.0 ${ }^{\circ} \mathrm{C}$, FT-IR $\left(v, \mathrm{~cm}^{-1}\right)$ : 1678 (-NH-C=O), 1596 (-C=O), 1517 (-C=C); ${ }^{1} \mathrm{H}-\mathrm{NMR}: 7.64$ (d, CH=CH, J=15.6), 
7.81 (d, $\mathrm{CH}=\mathrm{CH}, \mathrm{J}=15.6), 7.49$ - 8.29 (m, Ar), $2.23\left(\mathrm{~s}, \mathrm{OCCH}_{3}\right) ;{ }^{13} \mathrm{C}-\mathrm{NMR}: 189.0(\mathrm{C}=\mathrm{O}), 119.2(\mathrm{C} \alpha)$, $142.7(\mathrm{C} \beta), 141.5(\mathrm{C}-\mathrm{N}), 25.1\left(\mathrm{OCCH}_{3}\right)$; Anal. Calc. for $\mathrm{C}_{17} \mathrm{H}_{14} \mathrm{~N}_{2} \mathrm{O}_{4}(\mathrm{MW}=310.30) \mathrm{C}: 65.80, \mathrm{H}$ : 4.55, N: 9.03, found C: 65.76, H: 4.51, N: 8.98.

$N-(4-\{(2 E)-3-[4-(d i m e t h y l a m i n o) p h e n y l]$ prop-2-enoyl $\}$ phenyl)acetamide (7): Yield = 72 \%; m.p.: $150.9-154.7{ }^{\circ} \mathrm{C}$, FT-IR ( $\left.v \mathrm{~cm}^{-1}\right): 1684(-\mathrm{NH}-\mathrm{C}=\mathrm{O}), 1646(-\mathrm{C}=\mathrm{O}), 1597$ (-C=C); ${ }^{1} \mathrm{H}-\mathrm{NMR}: 7.59$ (d,

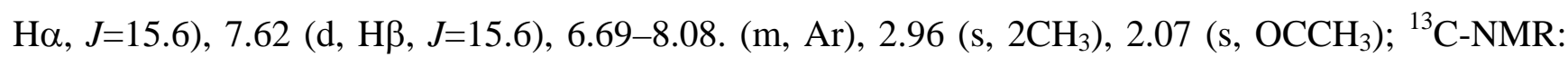
189.0(C=O), $120.4(\mathrm{C} \alpha), 145.64(\mathrm{C} \beta), 144.34(\mathrm{C}-\mathrm{N}), 168.9(\mathrm{~N}-\mathrm{C}=\mathrm{O}), 39.5\left(\mathrm{~N}_{-} \mathrm{CH}_{3}\right), 24.5\left(-\mathrm{CH}_{3}\right)$; Anal. Calc. for $\mathrm{C}_{18} \mathrm{H}_{17} \mathrm{NO}_{2}(\mathrm{MW}=279.33) \mathrm{C}: 77.40, \mathrm{H}: 6.13, \mathrm{~N}: 5.01$, found $\mathrm{C}: 77.31, \mathrm{H}: 6.10, \mathrm{~N}$ : 5.03 .

$N$-\{4-[(2E)-3-(2-thienyl)prop-2-enoyl]phenyl\}acetamide (8): Yield = 90 \%; m.p.: 147.8-149.3 ${ }^{\circ} \mathrm{C}$; FT-

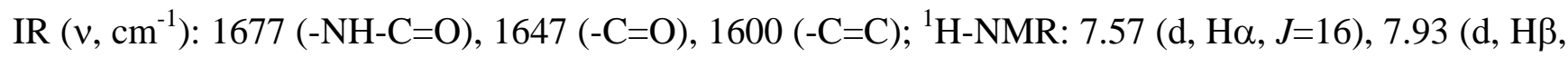
$J=16), 7.82-8.10$ (d, Ar), 7.66-7.17 (m, thienyl) 3.08 (s, $\left.\mathrm{OCCH}_{3}\right) ;{ }^{13} \mathrm{C}-\mathrm{NMR}: 187.8(\mathrm{C}=\mathrm{O}), 121.2$ $(\mathrm{C} \alpha), 136.8(\mathrm{C} \beta), 144.6(\mathrm{C}-\mathrm{N}), 169.5(\mathrm{~N}-\mathrm{C}=\mathrm{O}), 141.2,130.0(\mathrm{~S}-\mathrm{C}), 23.8\left(-\mathrm{CH}_{3}\right)$; Anal. Calc. for $\mathrm{C}_{15} \mathrm{H}_{13} \mathrm{NO}_{2} \mathrm{~S}(\mathrm{MW}=271.33) \mathrm{C}: 66.40, \mathrm{H}: 4.83, \mathrm{~N}: 5.16$, found $\mathrm{C}: 66.37, \mathrm{H}: 4.79, \mathrm{~N}: 5.13$.

$N$-\{4-[(2E)-3-(2-furyl)prop-2-enoyl]phenyl\}acetamide (9): Yield = 95 \%; m.p.: 118.1-119.0 ${ }^{\circ} \mathrm{C}$; FT-IR

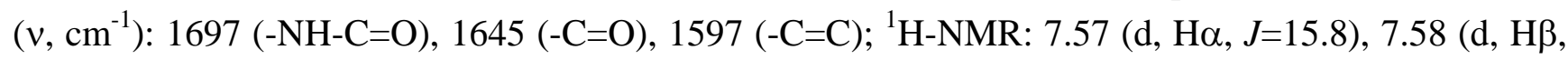
$J=15.8$ ), $7.82-8.09$ (d, Ar), 7.76 - 6.63 (m, furyl), 3.01 (s, $\left.\mathrm{OCCH}_{3}\right) ;{ }^{13} \mathrm{C}-\mathrm{NMR}: 187.2$ (C=O), 119.1 (C $\alpha), 129.9(\mathrm{C} \beta), 144.0(\mathrm{C}-\mathrm{N}), 168.9(\mathrm{~N}-\mathrm{C}=\mathrm{O}), 145.6,152.1(\mathrm{O}-\mathrm{C}), 23.8\left(-\mathrm{CH}_{3}\right)$; Anal. Calc. for $\mathrm{C}_{15} \mathrm{H}_{13} \mathrm{NO}_{3}(\mathrm{MW}=255.27) \mathrm{C}: 70.58, \mathrm{H}: 5.13, \mathrm{~N}: 5.49$, found $\mathrm{C}: 70.55, \mathrm{H}: 5.08, \mathrm{~N}: 5.37$.

\section{Pharmacology: Animals}

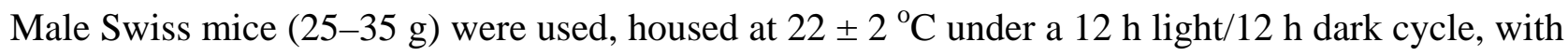
access to food and water ad libitum. The experiments were performed during the light phase of the cycle. The animals were acclimatized to the laboratory for at least $2 \mathrm{~h}$ before testing, and were used once throughout the experiments. All the experiments reported in this study were carried out in accordance with the current guidelines for the care of laboratory animals and the ethical guidelines for investigation of experimental pain in conscious animals [15].

\section{Drugs}

The following chemicals were used: acetic acid, formalin, capsaicin (Calbiochem, San Diego, CA, USA), and morphine hydrochloride (Merck, Darmstadt, Germany). All the studied compounds, as well as the reference drugs, were dissolved in Tween ${ }^{\circledR} 80$ (E. Merck) plus $0.9 \%$ of $\mathrm{NaCl}$ solution, with the exception of the capsaicin, which was dissolved in ethanol. The final concentrations of Tween ${ }^{\circledR} 80$ and ethanol did not exceed 5\% and did not cause any effects per se. 


\section{General pharmacological assay procedures}

\section{Acetic acid-induced writhing}

Abdominal constriction was induced in mice by intraperitoneal injection of acetic acid (0.6\%), as described by Collier et al. with minor modifications [16,17]. The animals were pre-treated intraperitoneally with the studied compounds (3, 6 and $10 \mathrm{mg} / \mathrm{kg}, 30 \mathrm{~min}$ before), except in the case of compound $6(0.1,0.5,1,3,10 \mathrm{mg} / \mathrm{kg})$. The control animals received a similar volume of saline solution $(10 \mathrm{~mL} / \mathrm{kg})$. The number of abdominal constrictions (full extension of both hind paws) was cumulatively counted over a period of $20 \mathrm{~min}$. Antinociceptive activity was expressed as the reduction in the number of abdominal constrictions between the control animals and the mice pre-treated with the compounds.

\section{Formalin test}

The observation chamber was a glass cylinder of $20 \mathrm{~cm}$ in diameter, equipped with a mirror placed at a $45^{\circ}$ angle to allow clear observation of the animals' paws. The mice were treated with $0.9 \%$ saline solution (i.p.) or compound 6 (10 mg/kg, i.p.) $30 \mathrm{~min}$ before formalin injection. Each animal was placed in the chamber for 5 min before treatment, in order to allow acclimatization to the new environment. The formalin test was carried out as described by Hunskaar and Hole, with minor modifications [17,18]. A $2.5 \%$ formalin solution $(0.92 \%$ formaldehyde, $20 \mu \mathrm{L})$ in $0.9 \%$ saline solution were injected intraplantarly into the right hind paw. The animal was then returned to the chamber and the amount of time spent licking the injected paw was considered as indicative of pain. Two distinct phases of intensive licking activity were identified: an early acute phase and a late or tonic phase (0-5 and 15-30 min after formalin injection, respectively).

\section{Capsaicin-induced nociception}

The procedure used was similar to that described previously [19]. After the adaptation period capsaicin (20 $\mu \mathrm{L}, 1.6 \mu \mathrm{g} / \mathrm{paw}$ ) was injected intraplantarly into the right hindpaw. The animals were observed individually for 5 min following capsaicin injection. The amount of time spent licking the injected paw was timed with a chronometer and was considered as indicative of nociception. The animals were treated with the compound 6 via i.p. (10 mg/kg) $30 \mathrm{~min}$ prior to capsaicin injection, respectively. The control animals received a similar volume of saline, intraperitoneally.

\section{Hot-plate test}

The hot-plate test was used to measure response latencies, according to the method described by Eddy and Leimback [20]. The mice were treated with saline solution, morphine (10 mg/kg, s.c.) or compound 6 (10 mg/kg, i.p.), and placed individually on a hot plate maintained at $56 \pm 1{ }^{\circ} \mathrm{C}$. The time between placing the animal on the hot plate and the occurrence of either the licking of the hind paws, shaking the paw or jumping off the surface was recorded as response latency. Mice with baseline 
latencies of more than $20 \mathrm{~s}$ were eliminated from the study and the cut-off time for the hot-plate latencies was set at $30 \mathrm{~s}$. The animals were treated $30 \mathrm{~min}$ before the assay.

\section{Statistical analysis}

The results are presented as mean \pm S.E.M., except for the ID values (i.e. the dose of compound $\mathbf{6}$ reducing the nociceptive response by $50 \%$, relative to the control value), which are reported as geometric means, accompanied by their respective $95 \%$ confidence limits. The $\mathrm{ID}_{50}$ value was determined by linear regression from individual experiments using the GraphPad software (GraphPad software, San Diego, CA). The statistical significance of the differences for the comparison between the groups and the control was detected by ANOVA, followed by Dunnett's multiple comparison test. P-values of less than $0.05(P<0.05)$ were considered indicative of significance.

\section{Acknowledgements}

The authors are grateful to CNPq and ProPPEC/UNIVALI (Brazil) for financial support.

\section{References}

1. Ni, L.; Meng, Q. M.; Siroski, J. A. Recent advances in therapeutic chalcones. Expert Opin. Ther. Pat. 2004, 14, 1669 - 1691.

2. Ahmad, S.; Israf., D. A.; Hj. Lajis, N.; Shaari, K.; Mohamed, H.; Wahab, A. A.; Ariffin, K. T.; Hoo, W. Y.; Aziz, N. A.; Kadir, A. A.; Sulaiman, M. R.; Somchit, M. N.. Cardamonin, inhibits pro-inflammatory mediators in activated RAW 264.7 cells and whole blood. Eur. J. Pharmacol. 2006, 538, 188 - 194.

3. Suzuki, K.; Seung, B. H.; Sung, L. S.; Sanghyun, L.; Hoon, J S; Sil, L. Y.; Hyun, S. K.; Ohuchi, K. Synthesis and biological evaluation of new biphenyl ether thiazine derivatives. Ensho Saisei 2005, 25, 130 - 136.

4. Nowakowska, Z. A review of anti-infective and anti-inflammatory chalcones. Eur. J. Med. Chem. 2007, 42, 125 - 137.

5. Corrêa, R.; Pereira, M. A. S.; Buffon, D.; Santos, L.; Cechinel-Filho, V.; Santos, A. R. S.; Nunes, R. J. Antinociceptive properties of chalcones. Structure-activity relationships. Arch. Pharm. 2001, 334, $167-172$.

6. Campos-Buzzi, F.; Campos, J. P. de; Tonini, P. P.; Corrêa, R.; Yunes; R. A., Boeck, P.; CechinelFilho, V. Antinociceptive effects of synthetic chalcones obtained from xanthoxyline. Arch. Pharm. 2006, 339, 361 - 365.

7. Ram, V. J.; Saxena, A. S.; Srivastava, S.; Chandra, S. Bioorg. Oxygenated chalcones and bischalcones as potential antimalarial agents. Med. Chem. Lett. 2000, 10, 2159 - 2161.

8. Hunskaar, S.; Fasmer, O. B.; Hole, K. Formalin test in mice, a useful technique for evaluating mild analgesics. J. Neurosci. Methods 1985, 14, 69 - 76.

9. Shibata, M.; Ohkubo, T.; Takahaschi, H.; Inoki, R. Modified formalin test: characteristic biphasic pain response. Pain 1989, 38, 347 - 352. 
10. Abbott, F.V.; Franklin, K.B.J. Noncompetitive antagonism of morphine analgesia by diazepam in the formalin test. Pharmacol. Biochem. Behav. 1986, 24, 319 - 321.

11. Rosesnkranz, H. S.; Mermelstein, R. Mutagenicity and genotoxicity of nitroarenes. All nitrocontaining chemicals were not created equal. Mutat. Res. 1983, 114, 217 - 267.

12. Chung, K. T.; Murdock, C. A.; Zhou, Y.; Stevens, S. E. Jr.; Li, Y. S.; Wei, C. I.; Fernando, S. Y. Chou, M. W. Effects of the nitro-group on the mutagenicity and toxicity of some benzamines. Environ. Mol. Mutagen. 1996, 27, 67 - 74.

13. Michaux, C.; Charlier, C.; Julémont, F.; de Leval, X.; Dogné, J. M.; Pirotte, B.; Durant. F. A new potential cyclooxygenase-2 inhibitor, pyridinic analogue of nimesulide. Eur. J. Med. Chem. 2005, 40, $1316-1324$.

14. Satyanarayana, M.; Tiwari, P.; Tripathi, B. K.; Srivastava, A. K.; Pratap, R. Synthesis and antihyperglycemic activity of chalcone based aryloxypropanolamines. Bioorg. Med. Chem. 2004, $12,883-889$.

15. Zimmerman, M. Ethical guidelines for investigations of experimental pain in conscious animals. Pain 1983, 16, 109 - 110.

16. Collier, H. D. J.; Dinnin, L. C.; Johnson, C. A.; Schneider, C. The abdominal constriction response and its suppression by analgesic drugs in the mouse. Br. J. Pharmacol. 1968, 32, 295 310.

17. Campos-Buzzi, F.; Corrêa, R.; De Souza, M. M.; Yunes, R. A.; Nunes, R. J.; Cechinel-Filho, V. Studies on new cyclic imides obtained from aminophenazone with analgesic properties. Drug Res. 2002, 52, 455 - 461.

18. Hunskaar, A. T.; Hole, K. The formalin test in mice: dissociation between inflammatory and noninflammatory pain. Pain 1987, 30, 103 - 104.

19. Sakurada, T.; Katsumata, K.; Tan-No, K.; Sakurada, S.; Kisara, K. The capsaicin test in mice for evaluating tachykinin antagonist in the spinal cord. Neuropharmacol. 1992, 31, 1279 - 1285.

20. Eddy, N. B.; Leimback, D. Synthetic analgesic. II. Dithienylbutenyl and dithienylbutylamines. J. Pharmacol. Exp. Ther. 1953, 107, 385 - 393.

Sample Availability: Contact the authors

(C) 2007 by MDPI (http://www.mdpi.org). Reproduction is permitted for noncommercial purposes. 